

\section{Daftar Isi (Table of Content) Journal of Government
Civil Society}

\begin{tabular}{|c|c|}
\hline \multirow{3}{*}{$145-158$} & $\begin{array}{l}\text { Political Law's Reconstruction of Village Apparatus to Realize Independent } \\
\text { Village in Indonesia }\end{array}$ \\
\hline & Hartati $^{1}$, Pahrudin HM$^{2}$, Elita Rahmi ${ }^{1}$ \\
\hline & $\begin{array}{l}\text { ('Faculty of Law, Universitas Jambi, Indonesia) } \\
\text { ('Departement of Government Science, STISIP Nurdin Hamzah Jambi, Indonesia) }\end{array}$ \\
\hline \multirow{3}{*}{$159-179$} & $\begin{array}{l}\text { Policy of a Merit System to Make a Good and Clean Government in The } \\
\text { Middle of Bureaucratic Politicization }\end{array}$ \\
\hline & $\begin{array}{l}\text { Yahya Pandega Putra1, 2, Eko Priyo Purnomo, 2, Suswanta Suswanta1, } \\
\text { Aulia Nur Kasiwi1, }\end{array}$ \\
\hline & $\begin{array}{l}\text { ('Jusuf Kalla School of Government, Universitas Muhammadiyah Yogyakarta, Indonesia) } \\
\text { ('Department of Government Affairs and Administration, Universitas Muhammadiyah } \\
\text { Yogyakarta, Indonesia) }\end{array}$ \\
\hline \multirow{3}{*}{$181-199$} & $\begin{array}{l}\text { Smart Human Security: Economic Safety for Micro, Small and Medium } \\
\text { Enterprises (MSMEs) to Face The Impact of The Covid-19 Global Pandemic }\end{array}$ \\
\hline & Elyta $^{1}$, Warjio ${ }^{2}$, Ahmad Azrin Bin Adnan ${ }^{3}$ \\
\hline & $\begin{array}{l}\text { ('Faculty of Social and Political Sciences, Universitas Tanjungpura, Indonesia) } \\
\text { ('Faculty of Social and Political Sciences, Universitas Sumatera Utara, Indonesia) } \\
\text { ('Faculty of Business and Management, Universiti Sultan Zainal Abidin (UnisZa), } \\
\text { Trengganu, Malaysia) }\end{array}$ \\
\hline \multirow{3}{*}{$201-218$} & $\begin{array}{l}\text { Using The "Return on Investment" Strategy to Sustain Logistic Supply } \\
\text { Provider Toward Indonesia's Logistic Policy }\end{array}$ \\
\hline & Riska Rahayu $\mathbf{u}^{1,2}$, Eko Priyo Purnomo ${ }^{1,2}$, Ajree Ducol Malawani,1,3 \\
\hline & $\begin{array}{l}\text { ('1usuf Kalla School of Government, Universitas Muhammadiyah Yogyakarta, Indonesia) } \\
\text { ('Magister of Government and Public Affairs, Universitas Muhammadiyah Yogyakarta, } \\
\text { Indonesia) } \\
\text { ('Doctoral Program of Political Islam, Universitas Muhammadiyah Yogyakarta, Indonesia) }\end{array}$ \\
\hline \multirow{3}{*}{$219-228$} & $\begin{array}{l}\text { Indonesia Universal Health Coverage Implementation on University } \\
\text { Students }\end{array}$ \\
\hline & Adityo Pratikno Ramadhan'1, Budiyono Budiyonoㄹ, Djonet Santoso' ${ }^{1}$ \\
\hline & ('Sustainable Development Goals Center, Universitas Bengkulu, Indonesia) \\
\hline
\end{tabular}


The Local Government of Kulon Progo Regency Innovation in Subduing Capitalism through Community Empowerment

229 - 247 Muhammad Eko Atmojo ${ }^{1}$, Helen Dian Fridayani ${ }^{2}$

('Departement of Government Science, Universitas Muhammadiyah Yogyakarta, Indonesia)

('Departement of Political Science, National Cheng Kung University, Taiwan)

Land Administration Policy In Bantul and Sleman Districts

$249-272$

Subekti Widiyasno1, Dyah Mutiarin 1, Herdin Arie Saputra1, Ikhwan

Rahmatika Latif ${ }^{1}$

('Department of Government Affairs and Administration, Universitas Muhammadiyah Yogyakarta, Indonesia)

Increasing Local Own-Source Revenue through The Development of The Regional Tourism Sector

$273-291$

Harries Madiistriyatno', Ida Musdafia Ibrahim², Dudung Hadiwijaya ${ }^{3}$

('Program Studi Magister Manajemen Sekolah Tinggi Manajemen IMMI, Indonesia) (2Program Studi Manajemen Sekolah Tinggi Ilmu Ekonomi Y.A.I, Indonesia)

(3Program Studi Manajemen, Universitas Muhammadiyah Tangerang, Indonesia) 


\title{
Indonesia Universal Health Coverage Implementation on University Students
}

\author{
Adityo Pratikno Ramadhan ${ }^{1 *}$, Budiyono Budiyono ${ }^{1}$, Djonet Santoso ${ }^{1}$ \\ ${ }^{1}$ Sustainable Development Goals Center, Universitas Bengkulu, Indonesia \\ *Email Correspondence: ramadhan.adityo@gmail.com
}

\begin{abstract}
This research aimed to investigate the percentage of university students at the University of Bengkulu, Indonesia, who participated in the national health insurance program, and why the students did or did not participate in the national health insurance program. This research was performed with the inductive approach and sampled 366 university undergraduate students from eight faculties at the University of Bengkulu, Indonesia. The data collection was conducted by survey technique using a questionnaire. The results show that only 58.2\% of university students who participated in the national health insurance program and their parents played an important role in determining whether they participated in the program. Pseudo universal health coverage would probably happen in Indonesia since some students participated in the national health insurance program. However, their premium payments were overdue, so that their insurance coverage became inactive. The unique finding of this research is that 1.96 percent of students mentioned that they did not participate in the national health insurance program because they perceived this program categorized as usury, which is forbidden in Islam.
\end{abstract}

Keywords: Health, national health insurance, social policy, universal health coverage

\begin{abstract}
ABSTRAK
Penelitian ini bertujuan untuk mengetahui persentase mahasiswa Universitas Bengkulu yang mengikuti program jaminan kesehatan nasional, dan mengapa mahasiswa mengikuti atau tidak mengikuti program jaminan kesehatan nasional. Penelitian ini dilakukan dengan pendekatan induktif dan mengambil sampel 366 mahasiswa sarjana dari delapan fakultas di Universitas Bengkulu, Indonesia. Pengumpulan data dilakukan dengan teknik survei menggunakan kuesioner. Hasil penelitian menunjukkan bahwa hanya 58,2\% mahasiswa yang mengikuti program jaminan kesehatan nasional dan orang tuanya yang berperan penting dalam menentukan keikutsertaan mereka dalam program tersebut. Pertanggungan kesehatan universal semu mungkin akan terjadi di Indonesia karena beberapa pelajar berpartisipasi dalam program jaminan kesehatan nasional. Namun, pembayaran premi mereka terlambat, sehingga pertanggungan asuransinya menjadi tidak aktif. Temuan unik dari penelitian ini adalah 1,96 persen mahasiswa menyatakan tidak mengikuti program jaminan kesehatan nasional karena menganggap program ini termasuk riba yang dilarang dalam Islam.
\end{abstract}

Kata Kunci: Kesehatan, jaminan kesehatan nasional, kebijakan sosial, jaminan kesehatan universal.

Citation : Ramadhan, Adityo Pratikno, Budiyono, Djonet Santoso. 2020. "Indonesia Universal Health Coverage Implementation on University Students." Journal of Government and Civil Society 4(2):219228. 


\section{INTRODUCTION}

Indonesia has implemented the national social health insurance program since the $1^{\text {st }}$ of January 2014 and the Indonesian government is targeting to reach universal health coverage in 2019 (Pisani et al., 2017). By 2019, all Indonesian citizens will have participated in the national social health insurance program under the Social Security Administrative Body for Health or refer as BPJS.

However, the Indonesian government had already estimated in 2017 that the Universal Health Coverage (UHC) would not reach the target in 2019. This can be seen from Indonesian Presidential Decree No. 59/2017 about the Implementation of Sustainable Development Goals in Indonesia, stating that the target of Indonesia UHC is $95 \%$ in 2019.

Reaching the UHC target is not easy, particularly for Indonesia, a large population country. Thus, it takes time and incremental process to reach UHC (Lagomarsino et al., 2012). Indonesian government mentioned in their UHC report that the informal sector, of which unfortunately dominates Indonesia's labour market, is the main barrier to reaching the UHC since it is harder to persuade people working in this sector to participate in the national health insurance program (National Team for the Acceleration of Poverty Reduction, 2015).

Furthermore, research about universal health coverage in Indonesian has been conducted by previous researchers. Trisnantoro et al., (2014) discussed Indonesia universal health coverage in the dimension of financial and health access. Mboi, (2015) explained the process of establishing universal health coverage in Indonesia. Reich et al., (2016) investigated the universal health coverage process in 11 countries, including Indonesia. Meanwhile, Fossati, (2017) explored the political process in the national and local government for establishing universal health coverage in Indonesia. Wiseman et al., (2018) examined the equity impact of Indonesia universal health coverage reform. Wasir et al., (2019) defined pricing and reimbursement policy in Indonesia universal health coverage system in Indonesia, and Sharma et al., (2020) explored the main actors and priority setting of Indonesia universal health coverage.

Most of the aforementioned research were performed by academics, however, research concerning universal health coverage in relation to academics or university student is limited. Within 10 years, university students will have a vital role in the development of the country. Thus, it is necessary to conduct research about university students' involvement in the universal health coverage (UHC) program in Indonesia, including the participation rate of university students in the UHC program.

This research aimed to investigate the percentage of students at the University of Bengkulu participating in the national health insurance program and why they did or did not participate in the program. To achieve this objective, the research was conducted 
on one population where undergraduate students in a university were chosen as the population.

This paper is divided into five sections, started by the introduction explaining the UHC implementation and UHC barriers in Indonesia and the research objective. Then, the research location overview that briefly describes the research location is presented, followed by the research method. The results and the analysis are discussed in two subsections: the reasons for NOT participating and participating in national health insurance. Finally, the conclusion and recommendation are also provided.

\section{RESEARCH LOCATION OVERVIEW}

This research was conducted at the University of Bengkulu, one of the state universities in Indonesia, located in the Province of Bengkulu. The province has a population of 1.8 million people, a poverty rate of $15.43 \%$ of the population (BPS, 2018). Since the percentage poverty rate in Bengkulu Province is above the Indonesia national percentage of poverty rate $(9,8 \%$ of the total population) (World Bank, 2018), Bengkulu Province is categorized as a province with a high poverty rate. Also, this research was performed in Bengkulu because it has the highest poverty rate in Sumatera Island. On the other hand, UHC is one of the crucial social safety nets for poor people. Thus, the UHC is urgently needed by the poor, but others also need it to protect them from falling into the poverty zone. The research regarding UHC and the poor has been performed by many scholars. Hence, this research investigate from a different angle, which is the UHC implementation on university students (consisting of not only the poor but also the middle and upper-class people). The University of Bengkulu is the largest and the best in Bengkulu, and the students are varying in terms of socio-economic status. Thus, this research was performed at the University of Bengkulu.

The University of Bengkulu was established in 1982 and currently has eight faculties, 44 undergraduate departments, 21 master degree departments, and two doctoral degree departments. This university is located in Bengkulu Province, Sumatera Island, one of five big islands in Indonesia. The University of Bengkulu is the only public university in Bengkulu Province under the Ministry of Education and Culture. The university has almost 14 thousand undergraduate students, and all the samples of this research were undergraduate students. They are not only from Bengkulu Province but also from other provinces in Indonesia. 


\section{RESEARCH METHOD}

In the beginning, this research conducted a library study to find the cutting edge theory, research and current condition of the universal health coverage implementation in Indonesia, particularly Bengkulu Province. Next, this research employed an inductive approach, an approach that builds theory, to address the aim of this research. Also, the survey study was used in this research as a research method and this is descriptive research based on Bhattacherjee (2012). The population of the research was the undergraduate students of the University of Bengkulu. The samples were 366 students, from the aggregate of $10 \%$ of the total number of undergraduate students intake in the 2017 academic year on every faculty in the University of Bengkulu). However, the research samples consisted not only students from the 2017 intake year but also students from 2015, 2016, 2018 intake years. The students involved in this research were between 17 to 22 years old. Every faculty had a different number of students in the samples. Depending on the current total number of students in that faculty, the bigger the number of students, the more samples of students were taken from that faculty. The student samples were chosen randomly; however, the student's academic year intake was still considered. Therefore, the total number of student samples based on the intake year was generally equal.

Data collection in this research was conducted using questionnaires administered to the respondents. The questionnaires were divided into two types: a questionnaire for those who joined the national health insurance program and those who did not. The questionnaires for those who joined the national health insurance program had 12 questions, while the other had nine questions. The first six questions were about the respondents' background, such as age, intake year, gender, faculty, student number, and date when the survey was conducted. This research used three enumerators, undergraduate students, for data collection. Subsequently, data were counted, tabulated, and transformed into percentages before being analysed. The data collection process was conducted from August to September 2018.

\section{RESULTS}

This research found that only $58,2 \%$ of students participated in the national health insurance. This result was very surprising and out of expectation because university students are known as a well-educated citizen, familiar with technology, such as gadget and internet, and connected to each other. Thus, they were supposed to be well-informed about government programs, including national health insurance. This research also investigated why students participated or not in the national health insurance program. 


\section{The Reasons for NOT Participating in The National Health Insurance}

Several open questions were provided in the questionnaires to examine why the students did not participate in the national health insurance program. Hence, the respondents answered the questions by filling the blank and crossing one of the options provided in the questionnaires. The students' answers revealed six different reasons why students did not participate in the program.

\section{Table 1. The Reasons Students are not Participating in The National Health Insur-} ance Program

\begin{tabular}{lc}
\hline \multicolumn{1}{c}{ Reasons Not Participating } & Percentage (\%) \\
\hline $\begin{array}{l}\text { No time to go to the BPJS office for } \\
\text { registration }\end{array}$ & 35.95 \\
Not well informed regarding the national & 26.8 \\
health insurance program & \\
Following parents decision & 16.99 \\
Not interested in joining & 16.34 \\
Usury & 1.96 \\
Reason not mentioned & 1.96 \\
\hline
\end{tabular}

Source: Authors

The majority of students $(35.95 \%)$ did not participate in the national health insurance program because they had no time to go to the BPJS office to do the registration. It takes 30 minutes by car or motorcycles and around one hour by public transportation from the campus to the BPJS office. Furthermore, in the BPJS office, there was often a long queue for the insurance registration process, and it took approximately one hour in the queue to reach the registration desk. Moreover, the BPJS office was only open on weekdays and served during office hours, which conflicted with the university students' class schedules. However, BPJS has programmed national health insurance online registration. People do not need to go to the BPJS office to register because it can be done through a smartphone application.

$26,8 \%$ students did not participate because they were not well-informed about the national health insurance program. This is bizarre because the information regarding the national health insurance is available in every Indonesia online news, social media and advertisements in some famous Indonesian websites. The missing link might happen somewhere here. However, since finding the missing link was not the focus of this research, there will be no further explanation about it. Furthermore, 16,9\% did not participate in the national health insurance program because they followed their parents' path and did 
not participate. This finding reveals that parents gave a domino effect in terms of students' national health insurance participation. When the parents decided not to participate, their children would likely follow their decision as well. Also, 16,34\% of the students were not interested in joining (without providing specific reasons) and thus did not participate.

This research reveals an unique finding, that $1,96 \%$ of students said they did not participate in the national health insurance program because they perceived the national health insurance categorized as usury. In Islamic teachings, usury is forbidden and if someone performs or involves usury, he or she commits a great sin. However, not all Muslims agree that the national health insurance categorized as usury. Nevertheless, if some Muslims in Indonesia believe that the national health insurance program involves usury, Indonesia will never reach the target of universal health coverage as a country with the biggest Muslim population. A small number of students $(1.96 \%)$ did not mention their reason for not participating in the program.

This research also explored whether the students who did not participate plan to participate in the national health insurance in the future. It was found that $80.39 \%$ students said they intend to participate in the future, while $19.61 \%$ did not.

\section{The Reason for Participating in National Health Insurance}

Besides investigating non-participation, this research also asked why students participated in the national health insurance program.

\section{Table 2. The Reasons Students Participated in National Health Insurance}

\begin{tabular}{lc}
\hline \multicolumn{1}{c}{ Reasons Participating } & Percentage (\%) \\
\hline Benefits of national health insurance & 68.54 \\
\hline Following parents decision & 28.17 \\
\hline Not mentioned their reason & 3.29 \\
\hline
\end{tabular}

Source: Authors

The data presented in Table 2 reveal that some students were already well-informed of the national health insurance, indicated by their answers that most students participated in the national health insurance because of the insurance benefits. Again, parents played a decisive role in determining whether the students participated in the national health insurance program. This finding is in line with the results presented in the previous section; some students did not participate because they followed their parents. 
This research also investigated the impact on insurance participation as there is a type of national health insurance membership obtained through self-funding contribution. Individuals in this category must pay the insurance premium by themselves. This type of membership leads to a problem of overdue premium payment. When it is overdue, the health insurance coverage will be inactive, and the membership of the national health insurance will be inactive as well. The members must pay the overdue contribution and the penalty fees to reactivate the coverage and membership.

This research also revealed the number of students who participated in the national health insurance with overdue contribution payment (7.98\%). Furthermore, this research further investigated the reason why the students were overdue. It was revealed that $35.3 \%$ of the students did not know the schedule of payment and where to pay it; $29.4 \%$ could not afford to pay the insurance contribution; $17.6 \%$ would pay the insurance contribution once they needed the health service in a health facility; $17.6 \%$ refused to reveal their reasons of overdue payment. However, more attention was needed for the finding related to a group of people who could not afford the insurance premium. Since they could not pay the premium, then they were not covered by the health insurance program and could not access health services. If the overdue premium problem due to the inability to pay is unresolved, it will create a pseudo UHC in Indonesia. It means Indonesia may reach $\mathrm{UHC}$, but, in reality, many people are not yet covered by the national health insurance due to the overdue premium payment.

Another question that was asked to the students in this research was about carrying national health insurance card. According to the regulation of BPJS, the office managing the national health insurance, in order to obtain health insurance services, every member must show their card to the administrative officers in the health facilities when they need health service. Otherwise, they can obtain health services but are not covered by insurance. This research found that $38,97 \%$ of the students participated in the national health insurance program. However, they did not bring their health insurance cards when they were filling the research questionnaires.

\section{DISCUSSION}

From the results, some points can be drawn for discussion. First, information has a vital role in the implementation of UHC. People will decide to participate or not participate because of information they have. This is consistent with Banerjee et al., (2019) who mentioned that information plays decisive role to achieve universal health coverage. Second, parents have a domino effect in the UHC participation of their children. If the parents participate in the UHC program, then more likely the children will participate.

Third, the premium payment is an issue in national health insurance. Many members of national health insurance had overdue premium payment. This is in line with Agustina 
et al (2019), who argued that only a small number of people in wealth quintile Q2-Q3 participated in the UHC program. Furthermore, the wealth quintile Q1 participated in UHC because they have a premium payment subsidized by the government and wealth quintile Q5 participated in UHC because they have the ability to pay the premium on time (Agustina et al., 2019). However, this research found that some students performed overdue payment because of the unaffordability reason. Then, it is probably that not all people in Q1 wealth quintile are subsidized by government. This argument is consistent with Reich et al., (2016), who argued that the UHC system in Indonesia is still patchy because many of poor people did not have access to the UHC service; thus the system needs improvement and development. The problems of UHC implementation in Indonesia, such as overdue premium payment and people who do not participate in national health insurance due to unaffordability reason, must be solved immediately. Otherwise, this situation will undermine economic development since the UHC brings healthier people and eventually, good economic development as well (Frenk \& De Ferranti, 2012).

\section{CONCLUSION}

Indonesia is currently striving to reach the target of UHC. Some challenging issues emerge and must be resolved immediately, such as findings of this research: the low number of participants, the shortage information of UHC programs, the overdue premium payment and the reluctance of people to participate in UHC with unclear reasons. This research also found that some respondents perceived national health insurance as usury, an activity forbidden in Islam. It entails further research to examine why they categorized national health insurance as usury and investigate how many people have a similar perception. Second, this research also found that $19.61 \%$ of the students who did not participate in the national health insurance program stated that they were still unwilling to participate in the future. The reason was unknown, and further investigation is necessary to find their unwillingness reasons.

Furthermore, this research found that parents were important determinant factors for students to participate or not in the national health insurance program. Finally, UHC in Indonesia also has a problem concerning the premium payment. This research found an appellation, called Pseudo UHC. This term will emerge to perfectly describe the condition when Indonesia reaches the UHC target, but many people are not yet covered by the national health insurance program due to overdue premium payment. Consequently, they are no longer covered by the insurance until they have paid the premium. Suppose the overdue premium case happens due to the member's unaffordability, which often occurs in low-income families. In that case, this will deteriorate the poor's lives because they will not have access to health services when needed. Thus, they cannot work and eventually will be trapped in poverty condition. 


\section{REFERENCES}

Agustina, R., Dartanto, T., Sitompul, R., Susiloretni, K. A., Suparmi, Achadi, E. L., Taher, A., Wirawan, F., Sungkar, S., Sudarmono, P., Shankar, A. H., Thabrany, H., Susiloretni, K. A., Soewondo, P., Ahmad, S. A., Kurniawan, M., Hidayat, B., Pardede, D., Mundiharno, ... Khusun, H. (2019). Universal health coverage in Indonesia: concept, progress, and challenges. The Lancet, 393(10166), 75-102. https://doi.org/10.1016/ S0140-6736(18)31647-7

Banerjee, A., Finkelstein, A., Hanna, R., Olken, B. A., Ornaghi, A., \& Sumarto, S. (2019). The Challenges of Universal Health Insurance in Developing Countries: Evidence from a Large-Scale Randomized Experiment in Indonesia. NBER Working Paper, 37.

Bhattacherjee, A. (2012). Social Science Research: Principles, Methods, and Practices. In Textbooks Collection. Book 3. (2nd Editio). Textbooks Collection. https://doi.org/ 10.1186/1478-4505-9-2

BPS. (2018). National Statistic Board: Poverty Rate in Bengkulu Province 2010-2018. https:/ /bengkulu.bps.go.id/dynamictable/2016/10/03/6/penduduk-miskin-provinsibengkulu-2010-2018-kondisi-maret-.html

Fossati, D. (2017). From periphery to centre: Local government and the emergence of universal healthcare in Indonesia. Contemporary Southeast Asia, 39(1), 178-203. https:/ /doi.org/10.1355/cs39-1f

Frenk, J., \& De Ferranti, D. (2012). Universal health coverage: Good health, good economics. The Lancet, 380(9845), 862-864. https:// doi.org/10.1016/S0140-6736(12)61341-5

Lagomarsino, G., Garabrant, A., Adyas, A., Muga, R., \& Otoo, N. (2012). Moving towards universal health coverage: Health insurance reforms in nine developing countries in Africa and Asia. The Lancet, 380(9845), 933-943. https://doi.org/10.1016/S01406736(12)61147-7

Mboi, N. (2015). Indonesia: On the way to universal health care. Health Systems and Reform, 1(2), :91-97. https://doi.org/10.1080/23288604.2015.1020642

National Team for the Acceleration of Poverty Reduction. (2015). The Road to National Health Insurance. In Secretariat of the Vice President of the Republic of Indonesia. http:/ /www.anc.org.za/show.php?id=6013

Pisani, E., Kok, M. O., \& Nugroho, K. (2017). Indonesia's road to universal health coverage: A political journey. Health Policy and Planning, 32(2), 267-276. https://doi.org/ 10.1093/heapol/czw120

Reich, M. R., Harris, J., Ikegami, N., Maeda, A., Cashin, C., Araujo, E. C., Takemi, K., \& Evans, T. G. (2016). Moving towards universal health coverage: Lessons from 11 country studies. The Lancet, 387(10020), 811-816. https://doi.org/10.1016/S01406736(15)60002-2 
Sharma, M., Teerawattananon, Y., Luz, A., Li, R., Rattanavipapong, W., \& Dabak, S. (2020). Institutionalizing Evidence-Informed Priority Setting for Universal Health Coverage: Lessons From Indonesia. Inquiry (United States), 57. https:// doi.org/ $10.1177 / 0046958020924920$

Trisnantoro, L., Marthias, T., \& Harbianto, D. (2014). Universal Health Coverage Assessment Indonesia. In Global Network for Health Equity (GHNE) (Issue December). https:/ / doi.org/10.13140/RG.2.1.1174.7683

Wasir, R., Irawati, S., Makady, A., Postma, M., Goettsch, W., Buskens, E., \& Feenstra, T. (2019). Use of medicine pricing and reimbursement policies for universal health coverage in Indonesia. PLoS ONE, 14(2), 1-19. https://doi.org/10.1371/ journal.pone.0212328

Wiseman, V., Thabrany, H., Asante, A., Haemmerli, M., Kosen, S., Gilson, L., Mills, A., Hayen, A., Tangcharoensathien, V., \& Patcharanarumol, W. (2018). An evaluation of health systems equity in Indonesia: Study protocol. International Journal for Equity in Health, 17(1), 1-9. https:/ / doi.org/10.1186/s12939-018-0822-0

World Bank. (2018). The World Bank in Indonesia: overview. https://www.worldbank.org/ en/country/indonesia/overview

\section{ACKNOWLEDGEMENT}

The authors thank Sustainable Development Goals Center Universitas Bengkulu as for the publication funding for this research. The authors would also like to thank Dwi Pebriani Watu Mesa, Wica Meirani, and Yuniche Ilhami as enumerators for this research. The authors would also like to thank Elizar, Ph.D for her assistance as English language reviewer. 